\title{
Analysis of Technological Issues, Related to Processing of Alunite at Ganja Alumina Plant (GAP), and Ways of Their Solving
}

\author{
Eldar I. Taghiyev \\ Correspondence: Eldar I. Taghiyev, Kotršalova 301/ 12, 19600 Prague, Czech Republic. E-mail: eltag@tiscali.cz
}

Received: October 30, 2019 Accepted: December 5, 2019 Online Published: December 6, 2019

doi:10.5539/ijc.v12n1p69

URL: https://doi.org/10.5539/ijc.v12n1p69

\begin{abstract}
In 1965, the Ganja Alumina plant (GAP) started implementing an alkaline reduction technology for processing of alunite ore on an industrial scale. Technological deficiencies, together with design errors, led to unprofitable production. Since the plant was established, studies have been conducted to eliminate deficiencies in the reduction process, through alkaline technology and hardware design. A "reversed" scheme was developed for hydrochemical processing of alunite restored with the conversion of sodium sulphates using a $\mathrm{KOH}$ solution. Despite the elimination of several shortcomings in alkaline reduction technology, certain drawbacks remained, in particular: 1) significant emission of gas and dust from the kilns of fluidized bed furnace during roasting and recovery; 2) insufficient time for recovery of alunite powder, which complicates and worsens the technological and economic aspects of the process; 3) passivation of alumina in the roasting and reduction processes; 4) low yield alumina yield in the commercial product ( $\leq 75 \%)$; and 5) a significant amount of solid waste: 5 tonnes of red sludge per 1 tonne of $\mathrm{AL}_{2} \mathrm{O}_{3}$, and errors. As a result, the alunite ore processing line ceased production in 1992 and has not operated since.

This article is devoted to the development of new technologies and the improvement of a new potash-alkaline method and new soda-alkaline technology for processing alunite ores. The replacement of potash with soda (sodium carbonate), using new soda-alkaline technology, is proposed. Processing of solution from the first leach with sodium sulphate by conversion with $\mathrm{KCl}$ leads to production of $\mathrm{K}_{2} \mathrm{SO}_{4}$ and $\mathrm{NaCl}$. Use of the soda-alkaline technology allowed us to obtain the same products as with potash-alkaline technology, with an additional product - table salt. The fluidized bed furnace was replaced by a new type of kiln.
\end{abstract}

Keywords: alkaline reduction, reversed scheme, alumina, coagulant, potassium sulphate, quartz sand, table salt, conversion, potassium chloride, soda, potash

\section{Introduction}

Alunites are used as a raw material both in the production of aluminium and in the chemical industry. Alunite ores may serve for producing alumina, potassium sulphate, sulphuric acid, elementary sulphur, (Labutin, 1965) alum, (Nasirov, 2005), coagulant, (Lainer, 1982) quartz sand, and other products.

Alunite ores in mineral form are always accompanied by waste rock, consisting mainly of quartz and small quantities of other minerals, aluminosilicates and hematite.

Using ore from an alunite deposit from Azerbaijan, the Ganja Alumina Plant (GAP) applied technology that processed alunite ores, resulting in the production of alumina and other components. Globally, this was the first example of the use of such technology for mass production.

The integrated processing of alunites from the Zaghlik deposit at GAP was based on a alkaline reduction process, with additional production of potassium sulphate and table salt, by the conversion of sulphate waste using potassium chloride (Labutin, 1948), (Agranovsky, 1970). Conversion with $\mathrm{KCl}$ led to the production of $\mathrm{K}_{2} \mathrm{SO}_{4}$ and salt $(\mathrm{NaCl})$. However, the salt could not be used in the food industry because poisonous $\mathrm{V}_{2} \mathrm{O}_{5}$ (up to $0.05 \%$ in alunite ores) was accumulating in the reusable aluminate solution (in the form of sodium vanadate) and was further blended with a mixture of potassium and sodium sulphates.

The method involved the release of $\mathrm{SO}_{3}$, bound to alumina in alunite, at the beginning of the technological process.

The release occurs through the following reaction during the recovery of alunite rock using sulphur vapour or a gaseous reducing agent:

$$
(\mathrm{Na}, \mathrm{K})_{2} \mathrm{SO}_{4} \mathrm{Al}_{2}\left(\mathrm{SO}_{4}\right)_{3} .2 \mathrm{AL}_{2} \mathrm{O}_{3}+0,5 \mathrm{C}_{2} \mathrm{H}_{4}=3 \mathrm{AL}_{2} \mathrm{O}_{3}+(\mathrm{Na}, \mathrm{K})_{2} \mathrm{SO}_{4}+3 \mathrm{SO}_{2}+\mathrm{CO}_{2}+\mathrm{H}_{2} \mathrm{O}
$$


This process makes it possible to avoid the conversion of caustic alkali into a low value product, sodium sulphate, during leaching. For compensating the losses of caustic alkali during the technological cycle of alumina production, part of the sulphate salts was subjected to thermal caustification (Penyakov method).

The project was aimed at processing alunite ores from the Zaghlik deposit, composed of $51 \%$ alunite and $49 \%$ waste rock. The ore contains $0.05 \% \mathrm{~V}_{2} \mathrm{O}_{5}$. Averaging of the alunite content of the ore $(50 \%)$ was made by visual-mechanic enrichment of alunite ores in the mine.

Table 1. Average chemical composition of alunite ore from Zaghlik deposit (\% weight)

\begin{tabular}{llllllll}
\hline $\mathrm{AL}_{2} \mathrm{O}_{3}$ al & $\mathrm{AL}_{2} \mathrm{O}_{3}$ non-al & $\mathrm{SO}_{3}$ & $\mathrm{Na}_{2} \mathrm{O}$ & $\mathrm{K}_{2} \mathrm{O}$ & $\mathrm{SiO}_{2}$ quartz & $\mathrm{Fe}_{2} \mathrm{O}_{3}$ & Other \\
\hline 19.2 & 2.5 & 20.0 & $1.5-2.0$ & $3.5-4.0$ & $42-43$ & $4-5$ & $7.3-4.3$
\end{tabular}

Despite some advantages, this technological scheme had a number of significant deficiencies that, together with some plant design errors, complicated the production process and made it unprofitable, because the plant could not operate at full capacity.

\section{2. "Reversed" Scheme of Hydrochemical Processing of Recovered Alunite}

The search for ways to overcome the drawbacks of the alkaline reduction technology and hardware design errors began almost immediately after start of production (1965). In order to eliminate certain technological deficiencies, the plant switched to a new, "reversed" scheme of hydrochemical processing of recovered alunite, with the conversion of alkali sulphates by a $\mathrm{KOH}$ solution. This technology uses desilicated aluminate solution for evaporation (instead of mother liquor) in special evaporators, thus closing the water balance and separating sulphate salts. After evaporation and separation of sulphate salts, the aluminate solution is diluted to the necessary concentration prior to decomposition, using filtered wash water from the washing of alunite mud waste and wash water from washing of aluminium hydroxide. Alunite is leached by mother liquor, which is taken from the decomposition process.

\subsection{The Method of Compensation for the Loss of Alkali}

To compensate for the loss of the alkali, alkali sulphates are converted using potassium alkali, instead of sintering the hydrate-sulphate burden. All the alkali sulphates in the alunite, extracted during evaporation of desilicated aluminate solution, are converted into potassium sulphate and $\mathrm{NaOH}$, according to the reaction:

$$
\mathrm{Na}, 2 \mathrm{SO}_{4}+2 \mathrm{KOH}=\mathrm{K}_{2} \mathrm{SO}_{4}+2 \mathrm{NaOH}
$$

In this case, almost all the sodium sulphate is used for compensating for the losses of caustic alkali during production. The bulk of the potassium sulphate from the alunite will be extracted for production of the final product (fertilizer)

Conversion of alkali sulphates with $\mathrm{KOH}$ allowed us to eliminate certain deficiencies in reduction-alkaline technology:

1. The semi-finished product $\mathrm{Al}(\mathrm{OH})_{3}$ does not have to be returned to the starting stage for sintering.

2. The energy-intensive process of sintering of a hydrate-sulphate burden, emitting $\mathrm{SO}_{2}$ into the atmosphere, is completely eliminated from the scheme.

3. Production of inedible table salt, which is unprofitable, is also eliminated.

4. A mixture of potassium and sodium sulphates is extracted from the alumina solution before decomposition, thus speeding up the decomposition process, decreasing the level of pollution of aluminium hydroxide by sulphates, and also decreasing the dilution rate of the alumina solution.

The previous reducing agent (diesel fuel) was replaced by elementary sulphur, thus resolving the issue of manufacture of clear sulphuric acid. However, production was complicated by the need to arrange separate production of potassium alkali or procure it from third parties. However, certain important issues remained unresolved, even with the improved technology.

\subsection{The Main Mistake of the GAP Project Is the Use of Fluidized Bed Furnaces for Firing Alunite Ore}

A major error in furnace design caused a significant discharge of powder and gas from the fluidized layer furnaces during the roasting and reduction processes, as well as an insufficient dwelling time for the powder in the reduction furnace. The degree of powder recovery was therefore low. Powder from the furnaces was transferred to a recovery furnace and was circulating between the electrical filter and furnace. As result, the powder concentration at the entry to the electrical filters increased.

Use of fluidized layer furnaces for processing of alunite powder significantly complicated the technology and worsened the technical and economic results, although the concentration of $\mathrm{AL}_{2} \mathrm{O}_{3}$ in the powder was 1.5 times higher than in other types of rock. Because of the low degree reduction of aluminium sulphate in the powder, a significant part of the $\mathrm{NaOH}$ forms $\mathrm{Na}_{2} \mathrm{SO}_{4}$ during leaching. In addition, alunite powder for fluidized layer furnaces (FLF) is enriched by 
kaolin, which leads to the formation of insoluble sodium aluminosilicate $\mathrm{Na}_{2} \mathrm{OAL}_{2} \mathrm{O}_{3} 2 \mathrm{SiO}_{2} 2 \mathrm{H}_{2} \mathrm{O}$.

In other words, a significant part of the unrecoverable (sodium aluminosilicate), as well as recoverable losses (sodium sulphate) of caustic alkali, is caused by processing alunite powder at FLF.

As result of passivation and other losses during processing of the recovered alunite in the hydrochemical part of the Bayer process, the share of alumina in the final product did not exceed $75 \%$.

\section{Large Amount of Waste Per 1 Ton of Alumina and Other Deficiencies Led to The Shutdown of GAP}

In an improved hardware scheme, pulp from leaching of alunite rock was fed into a hydro-separator, where the insoluble residue was separated into two parts: fine, sludge fraction and larger, sand fraction of the mud. The sludge mud fraction was thickened in five-chamber thickeners, washed with a counterflow, then separated from alumina solution, re-pulped using water, and sent to a mud lake in the form of pulp (500-600 grams of solid matter per litre).

The sand fraction of the mud was separated from the alumina solution by filtration and rinsing at carousel vacuum filters and then sent to a mud lake. Waste for each tonne of alumina produced equalled 4 to 5 tonnes of red mud, including 1.5-2.0 tonnes of sludge fraction and 2.0-3.0 tonnes of sand fraction.

Purification of the aluminate solution from dissolved silica was carried out by one-stage desilication, in which, as a result of the reaction:

$$
\mathrm{NaOAL}_{2} \mathrm{O}_{3}+2,5 \mathrm{Na}_{2} \mathrm{OSiO}_{2}+\mathrm{nH}_{2} \mathrm{O}=\mathrm{Na}_{2} \mathrm{OAL}_{2} \mathrm{O}_{3} 2,5 \mathrm{SiO}_{2} \mathrm{nH}_{2} \mathrm{O}+5 \mathrm{NaOH}
$$

Sodium hydroaluminosilicate was precipitated and then removed after separation and rinsing.

Thus, the following significant technological issues remained unsolved.

1. Issue of roasting and reduction of alunite in FLF, and related deficiencies.

2. Low share of alumina in the final product (not more than $75 \%$ ).

3. Significant unrecoverable and recoverable losses of alkali, related to hydrochemical processing of alunite powder and ore, not fully recovered previously.

4. Significant quantities of disposed mud (white mud, sludge fraction, sands).

5. Significant consumption of scarce and expensive additional raw materials - elementary sulphur, potassium and sodium alkali. The scarcity of additional raw materials led to numerous month-long stops of GAP operation from 1990 to 1992.

Use of sulphur as a reducing agent led to an increase in the production of sulphuric acid (almost double), and complications related to its disposal.

Long-distance transportation of sulphuric acid is unprofitable.

In 1992, because of unresolved technological issues, production of alumina from alunite at GAP was ceased and has not commenced since then. The research also excluded process of alunite reducing from the technological scheme.

\section{Disadvantages of Alkaline Treatment of Raw Alunite}

Raw alunite was easily and rapidly degraded by solutions of caustic alkali. This property of a mineral was first used in the 1930s in a technology, described by S.P. Kamenetsky (Smirnov-Verin, 1938), and, more recently, by G. Z. Nasyrov (Sizyakov, 2001). However, these methods were not applied in production because they have the following deficiencies:

- Alkali consumption for leaching of raw alunite increased twofold.

- Leaching of alunitized rock required the use of highly diluted solutions of caustic alkali, with a concentration of $\mathrm{NaOH}$

$-\geq 10 \%$ of the solutions became almost saturated by sulphates.

- If a $10 \%$ solution of concentrated caustic alkali was used for leaching, the concentration of $\mathrm{AL}_{2} \mathrm{O}_{3}$ in an aluminate solution was around $50 \mathrm{grams} / \mathrm{l}$. The decomposition processes for such concentrations were ineffective, and the carbonization process was used instead.

- Compensation of losses of alkali by diaphragm electrolysis of potassium chloride, resulting in production of $\mathrm{KOH}$ and chloride, was an inefficient and expensive process, which also requires sideline processing of chloride on spot.

Low-temperature $\left(\leq 85^{\circ} \mathrm{C}\right)$ process of leaching of pre-crushed ore $(-8 \mathrm{~mm})$ decreases excited of alumina in the solution and increases leaching time. Possibly, for this reason, China refused to build a plant after pilot testing Nasyrov's technology (which was carried out over 20 years ago). 


\section{Potash Ridge Corp Project}

A Canadian company (Potash Ridge Corp. Project No 17M16, 2017) has developed another method of processing of alunite ore and production of sulphuric acid, sulphate of potassium (SOP), alumina, quartz sand from alunite ore for an alunite deposit in Utah (USA). After crushing and grinding, the alunite ore is subject to flotation treatment. As result, the ore contains not less than $60 \%$ of mineral alunite. Then, the ore is dried and roasted at $600{ }^{\circ} \mathrm{C}$ or below, with a simultaneous reduction of alunite by adding excess diesel fuel. The $\mathrm{SO}_{2}$ emitted is used for producing sulphuric acid, which is further used by PRC for processing of $\mathrm{KCl}$ at the deposit in Quebec (Canada) and for obtaining additional quantities of fertilizer $\mathrm{K}_{2} \mathrm{SO}_{4}$ and hydrochloric acid $(\mathrm{HCl})$. The roasted alunite is leached by the hot water for extraction of potassium sulphate in the solution (SOP). Roasting temperatures of less than $600{ }^{\circ} \mathrm{C}$ results in incomplete recovery of the alunite but enables the maintenance an active form of alumina in alunite. However, leaching of alunite, roasted at $600{ }^{\circ} \mathrm{C}$ by hot water leads to SOP losses because of the formation of basic salt, insoluble in water. The share of SOP in the solution does not exceed $65-70 \%$. Roasting at $800-900{ }^{\circ} \mathrm{C}$ improves the alunite reducing proportion up to $100 \%$ with extraction of $\mathrm{SO}_{3}$ by aluminium sulphate. In addition, the share of $\mathrm{SOP}$ is close to $100 \%$, however $¥-\mathrm{AL}_{2} \mathrm{O}_{3}$ changes into an insoluble form, $\alpha-\mathrm{AL}_{2} \mathrm{O}_{3}$. Consequently, the Bayer method of alumina extraction from the concentrate cannot be applied.

\section{Potash-Alkaline Technology of Alunite Ore}

A team of researchers at the Moscow Institute of Steel and Alloys (MISiS), led by Professor A. I. Layner, developed a potash-alkaline technology of alunite ore processing (Layner, 1974). This technology, which we further improved (Taghiyev, Patent of the Azerbaijan Republic No 0142, 2001, No 0210, 2003, Certificate of USSR \# 872456, 1981) (Scheme 1), was offered for reconstruction of a technological scheme of alunite ore processing at GAP. Besides an increase in productivity of up to 150.000 tonnes of $\mathrm{AL}_{2} \mathrm{O}_{3}$ per annum, it allows sideline production of:

1. Chloride-free fertilizer: 315.000 tonnes of potassium sulphate per annum;

2. 49.500 tonnes of coagulant (solid) for purification of drinking water and wastewater per annum;

3. Quartz sand for production of moulding and core mixtures for iron and non-ferrous casting, production of packing glass and construction materials: 300.000 tonnes per annum;

4. Pure carbon dioxide without harmful additions, which can be used for carbonating of mineral waters, electrical welding in protective environments, and in metallurgy, ecology and other areas: 60.000 tonnes of $\mathrm{CO}_{2}$ per annum.

We offered certain improvements to the hardware scheme, aimed at increasing the yield of alumina extracted from alunite ore. In particular, we offered to carry out fine crushing of 2 to $3 \mathrm{~mm}$. After roasting in rotary tube furnaces, roasted alunite should be subjected to wet grinding in ball mills (40-50 mesh) with a potash-carbonate mixture-based solution. The advantages of doing so are a) fluidized bed furnaces are not used for roasting, thus avoiding losses of powder; b) fine dry grinding is also not used, with the same positive effect.

Because of high content of alumina in the sand fraction after the first leaching (up to 15-20\%), we recommend transferring the pulp, resulting after the first leaching, sludge and sands are fed together to the second leaching in a circulating aluminate solution. In this case, the output of $\mathrm{Al}_{2} \mathrm{O}_{3}$ in the solution may reach up to $97 \%$. After the second leaching, the pulp is fed to a hydro-separator for separation into sludge and sands. Because of low solid matter in the sludge fraction pulp, the speed of deposition of the pulp in thickeners and washers may have risen between threefold and fourfold. The hardware scheme of potash-alkaline technology of alunite processing, which we proposed, eliminates almost all the deficiencies of reversed and alkaline reduction technologies. It also creates conditions for waste-free processing of alunite ore (Taghiyev E. I. 2006). The technology uses the existing GAP equipment. We rejected the use of FLF roasting because alunite and waste rock will be ground differently, and because of differences in their hardness: alunite - 3.5-4.0, a quartz- 7.5-8.0 on the Mohs scale. As result, the alumina content in the powder was 1.5 times higher than in the ore. 


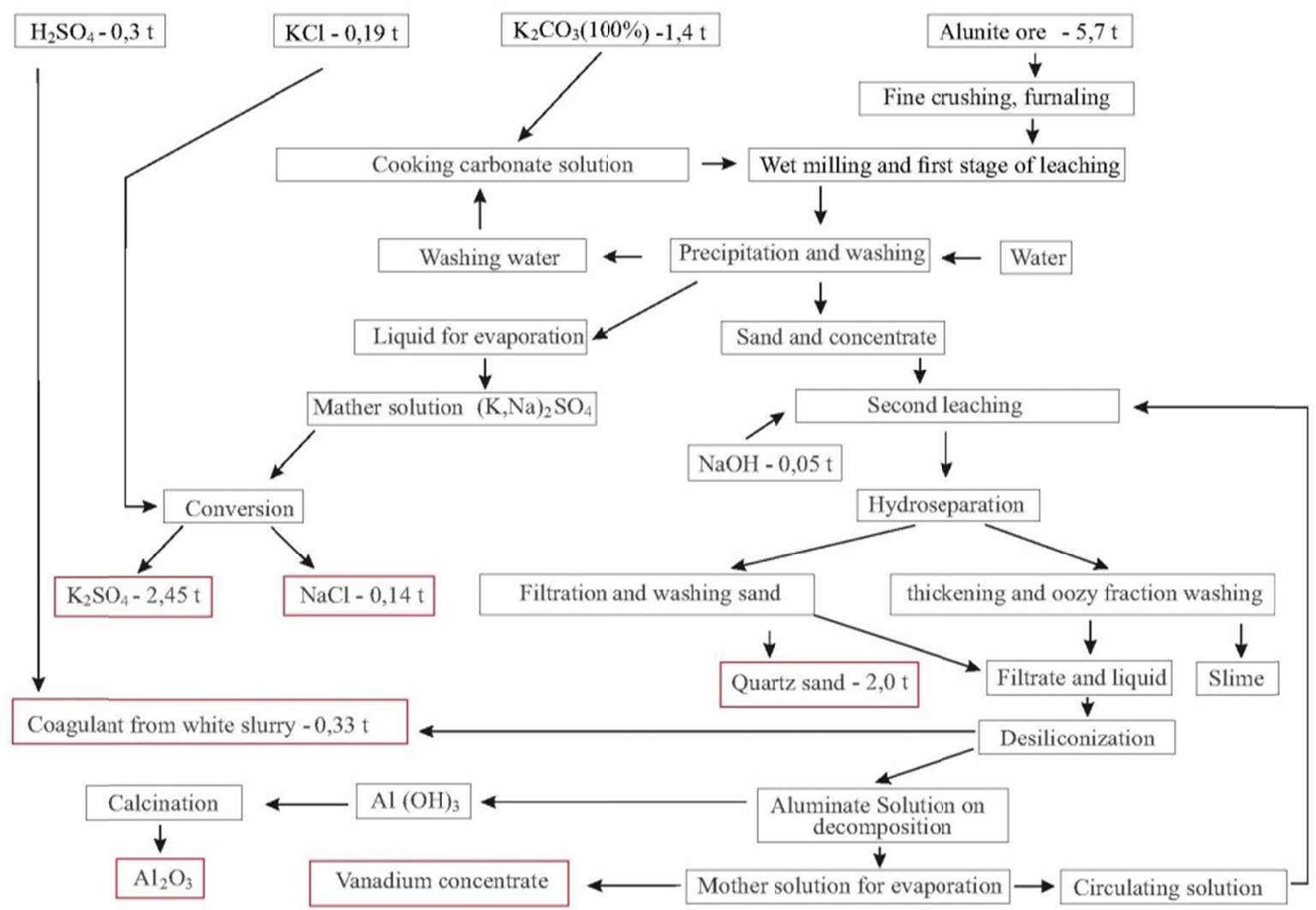

Scheme 1. Scheme of potash-alkaline technology processing of alunite ore

We proposed the use of a specially designed tubular rotary furnace for the roasting of alunite ore (Figure 1).

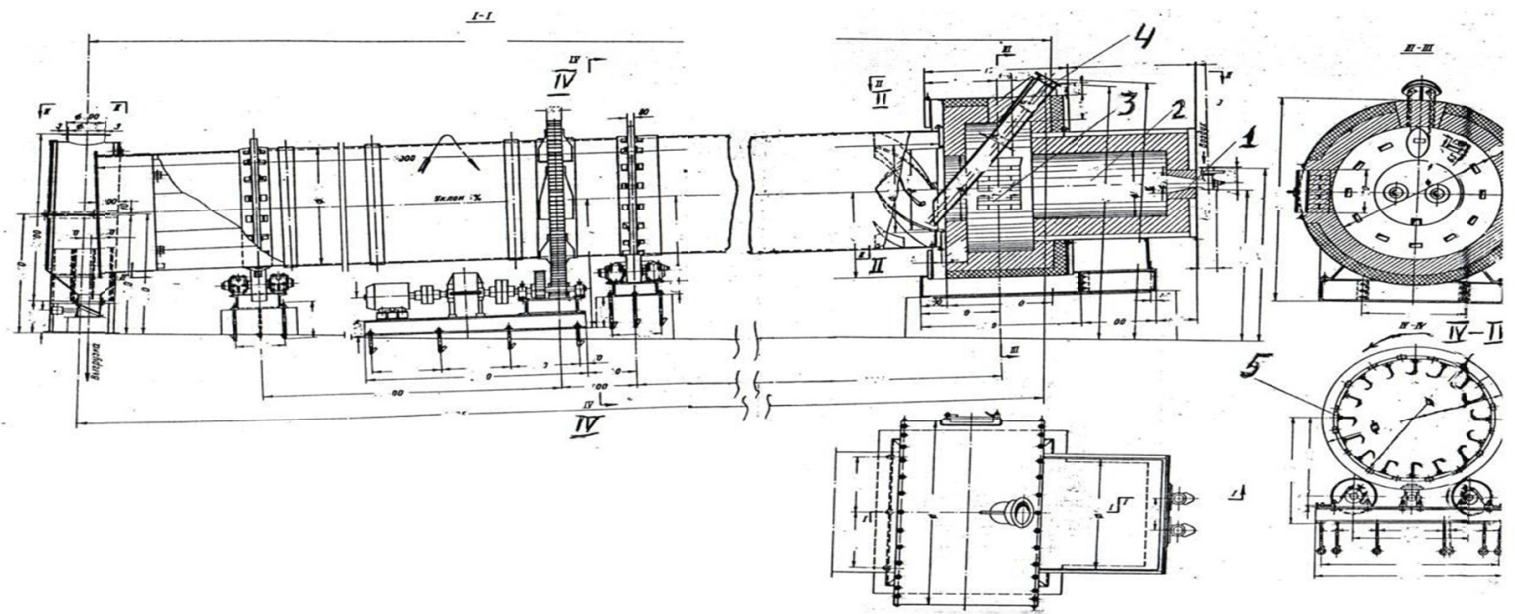

Figure 1. Tubular rotary furnace for roasting of alunite ore

1. Fuel and air injector

2. Combustion chamber

3. Output of combustion products to the furnace and regulation of gas temperature by air supply

4. Feed point for finely crushed alunite.

5. Section of the furnace. ( $|\vee-| \vee)$

The technology was successfully tested in laboratory conditions at GAP. In laboratory tests, the share of alkali and $\mathrm{SO}_{2}$, extracted into solution at the first leaching, was $90-95 \%$, and for alumina not more than $2 \%$. Insoluble residue from the first leaching of roasted alunite-concentrate, contains, on average, (\% weight): 
Table 2. Average chemical composition of the insoluble residue after the first leaching

\begin{tabular}{lllllllll}
\hline $\mathrm{SiO}_{2}$ & $\mathrm{AL}_{2} \mathrm{O}_{3}$ & $\mathrm{Fe}_{2} \mathrm{O}_{3}$ & $\mathrm{CaO}$ & $\mathrm{K}_{2} \mathrm{O}$ & $\mathrm{Na}_{2} \mathrm{O}$ & $\mathrm{SO}_{3}$ & $\mathrm{LOI}$ & Others \\
$35-36$ & $33-34$ & $3.0-4.0$ & $1.5-1.8$ & $0.4-0.5$ & $0.1-0.2$ & $0.2-0.3$ & $15-20$ & $4.0-5.1$ \\
\hline
\end{tabular}

In contrast, the share of $\mathrm{AL}_{2} \mathrm{O}_{3}$ in the initial alunite ore from the Zaghlik deposit did not exceed $19-20 \%$.

The share of major components of concentrate in the solution after the second leaching by the recycled aluminate solution is (in \%): $\mathrm{AL}_{2} \mathrm{O}_{3}-93-94 ; \mathrm{K}_{2} \mathrm{O}-52-53 ; \mathrm{N}_{2} \mathrm{O}-34-35 ; \mathrm{SO}_{3}-46-47$. The share of alumina in the resulting product is not less than $90 \%$.

Technologies for processing solid waste: white sludge, quartz sand, and clay fraction of mud were tested on the pilot plants at GAP, at the foundry of the Baku Engineering Plant, Salyan water purification station, etc. (positive results of the tests were officially confirmed).

Potash-alkaline technology (roasted alunite at $\mathrm{T}$ - roast $=520-530{ }^{\circ} \mathrm{C}$ treatment by potassium carbonate solution) allows the conversion of a sulphuric acid radical and alkali of sulphate alunite into a solution with the formation of potassium sulphate (chloride-free potassium fertilizer). Almost all the alumina from the ore (98\%) remains in an insoluble residue and, after the second leaching with recycled aluminate solution, goes into solution with the formation of sodium aluminate. In other words, insoluble residue after first leaching can be easily and profitably processed by Bayer out-of-autoclave process, with a number of benefits:

1. the share of alumina recovery in the product reaches up to $90 \%$;

2. we excluded a complicated process of reducing alunite by elementary sulphur, causing passivation of alumina, emission of gas and powder, and losses of alkali and sulphur;

3. we also avoided:

- production of sulphuric acid;

- the need for imported additional raw materials - elementary sulphur, potassium alkali;

- we excluded unrecoverable losses of alumina in the production of coagulant for the purification of drinking water and wastewater because of the use of sodium aluminosilicate (white slag);

- accumulation of large quantities of alkali sulphates in the hydrochemical part of the Bayer process.

Significant shortcomings of potash-alkaline technology are the high cost and scarcity of additional raw material potassium carbonate $\mathrm{K}_{2}\left(\mathrm{CO}_{3}\right)$. For countries that have large alunite ore reserves (China, Iran and Russia) and where nepheline processing is carried out by sintering with potassium carbonate as a by-product and, potash-alkaline technology will be the most effective. Potassium carbonate, obtained from processing nepheline, is used in potash-alkaline technology for processing roasted alunite.

In most countries, large deposits of alunite ore or potassium carbonate (potash) are a very scarce and are expensive product. Such scarcity thus limits their use for large-capacity production of alumina. A number of international research papers on technology of alunite ore processing (Alizadeh, 2016) consider potassium carbonate technology an optimal strategy of choice. (Piga, 1999)

\section{Elimination of the Lack of Potash-Alkaline Method}

To avoid the above shortcomings - use of scarce and expensive potassium carbonate - we offered a soda-alkaline technology for processing alunite ore (Taghiyev, 2018). In the first stage of leaching of roasted alunite, we used soda $\left(\mathrm{Na}_{2} \mathrm{CO}_{3}\right)$ instead of potash. The resulting solution contained potassium and sodium sulphates and $\mathrm{SO}_{3}$ of sulphate aluminium, although almost all the alumina remained in the insoluble residue. Then, the insoluble residue is processed in a Bayer out-of-autoclave process (as in the potash-alkaline technology) and in results in alumina, quartz sand. White sludge from the desilication process can be further used as a solid coagulant for water purification (Taghiyev, USSR author certificate 872456,1981 .)

The solution after the first leaching, a mixture of sodium and potassium sulphates, is subject to conversion with $\mathrm{Na}_{2} \mathrm{SO}_{4}$ and $\mathrm{KCl}$, as result of which we obtained SOP (sulphate of potassium), $\mathrm{K}_{2} \mathrm{SO}_{4}$ and edible table salt $\mathrm{NaCl}$. (Nemets, 1995) Earlier, GAP used a conversion process for processing of mixtures of $\mathrm{K}$ and $\mathrm{Na}$ sulphates, which were vaporized from an aluminate solution. As the solution contained a poisonous vanadium pentoxide, the table salt was inedible. (Taghiyev, 2006).

We avoid this drawback in the soda-alkaline technology. The first leaching of roasted alunite, with a solution of sodium carbonate, resulted in the production of potassium and sodium sulphates, and vanadium pentoxide remained in an insoluble residue. Later, during second leaching of the insoluble residue, the recycled aluminate solution, $\mathrm{V}_{2} \mathrm{O}_{5}$ went into solution in the form of sodium vanadate. It was then accumulated in a recycled aluminate solution until, after 
several cycles, it reached a certain concentration and became a concentrate of vanadium pulp during evaporation. The major products of soda-alkaline technology processing of alunite ore are metallurgical alumina, sulphate of potassium (SOP), coagulant for water purification, edible table salt, quartz sand, pure carbon dioxide, and vanadium sludge concentrate (E.I. Taghiyev 2019).

See below the hardware-technological scheme of a pilot plant at GAP, for soda-alkaline technology processing of alunite ore. The planning of this scheme takes into account equipment already available at the plant (Figure 2).

Figure 2: Hardware-technological scheme of a pilot plant, using soda-alkaline technology for processing alunite ore at the Ganja Alumina Plant.

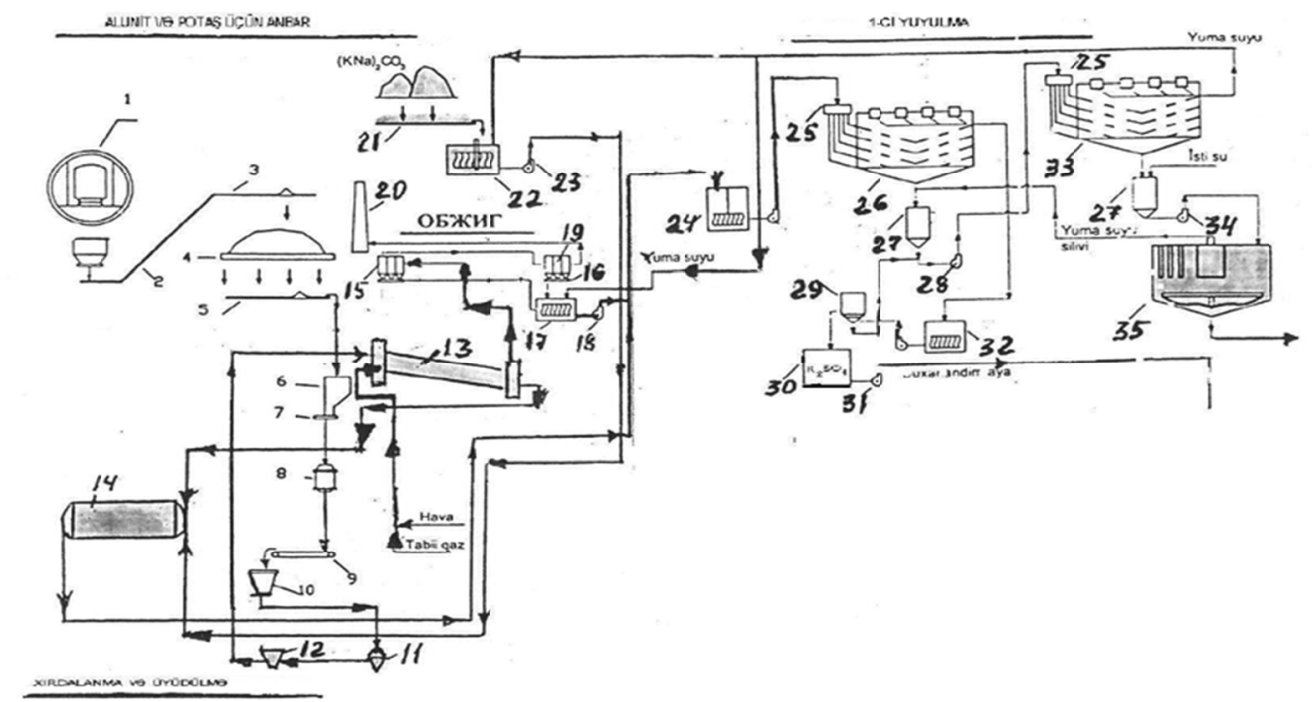

Figure 2. Hardware-technological scheme of a pilot plant, using soda-alkaline technology for processing of alunite ore at the Ganja Alumina Plant

1. Car dumper: 2. Belt conveyor: 3. Belt chute conveyor, with a dropping cart: 4. Belt chute conveyor: 5 . Belt conveyor: 6 . Alunite bin: 7. Electro-vibrating feeder: 8. Crusher (KMDT 2200/600): 9. Belt chute conveyor: 10. Bin for crushed alunite: 11. Fine crusher: 12. Bin for finely crushed alunite: 13 . Tubular rotary furnace for roasting: 14 . Ball mill for wet grinding: 15. Electrical filter GP55 3Y: 16. Screw: 17. Mixer: 18. Pump: 19. Electrical filter OG-4-16: 20. Pipe (free air): 21. Soda warehouse. 22. Mixer: 23. Pump: 24. Mixing and leaching machine: 25. Distributor: 26. Five-chamber thickener: 27. Mixer: 28. Pump: 29.Filter-LVANZh-125: 30. Mixer for solution $\mathrm{K}_{2} \mathrm{SO}_{4} ; \mathrm{Na}_{2} \mathrm{SO}_{4} ; 31$. Pump: 32. Mixer for thickener dump: 33. Washer: 34. Pump: 35. Filter-thickener.

Note: 1. Mixer 30 and pump 31 feed solution of $\mathrm{K}_{2} \mathrm{SO}_{4}, \mathrm{Na}_{2} \mathrm{SO}_{4}$ for conversion by Na2SO 4 with potassium chloride $\mathrm{KCl}$ and further evaporation and obtaining $\mathrm{K}_{2} \mathrm{SO}_{4}$ and $\mathrm{NaCl}$.

To reduce the capital costs of technology implementation, the author proposes dividing the implementation process into two stages.

The first stage is to introduce a part of the technology with the first leaching of the burnt alunite with a solution of soda (Na2CO3) with the separation of the insoluble residue (concentrate) for storage. The resulting solution of a mixture of sulphates of potassium and sodium to apply for a conversion of potassium chloride with obtaining sulphate of potassium (SOP) and sodium chloride (NaCL). The profit from the sale of products of the first stage of production will go to the construction of the alumina part of the introduction of the proposed soda-alkaline technology.

The advantages of potash-alkaline and soda-alkaline technologies in comparison with available "inverted" and alkaline reduction technologies.

1. Contents of alumina in the final product increases to $90 \%$.

2. Processing of alunite ore is carried out in an integrated manner with production of metallurgical alumina, potassium sulphate, coagulant for water purification, quartz sand, edible table salt, and clean $\mathrm{CO}_{2}$, all of which can be used in carbonating of mineral water and other areas.

3. Roasting of finely crushed ore (2-3 mm in diameter) and use of tubular rotary furnace excludes pollution. 
4. Roasting of alunite at $\mathrm{T}=520-530{ }^{\circ} \mathrm{C}$ with excessive air (in an oxidizing atmosphere) excludes the release of $\mathrm{SO}_{2}$ alunite during roasting, as well as passivation of alumina.

5. Application of wet grinding of roasted alunite with potassium carbonate solution (potash-alkaline method), or sodium carbonate solution (soda-alkaline method) with simultaneous first leaching excludes pollution of powder during grinding in a drum mill.

6. After the first leaching in the insoluble residue, the remains of the concentrate $\left(33-34 \% \mathrm{AL}_{2} \mathrm{O}_{3}\right)$ are processed in a Bayer out-of-autoclave process.

7. White sludge from desilication is used for the production of solid coagulant for the purification of drinking water and wastewater from mechanical impurities.

8. Edible salt: one of the outputs of potash-alkaline and soda-alkaline technologies - does not contain any vanadium pentoxide. Pulp, containing all of vanadium pentoxide, is separated from it.

9. Red mud: quartz sand ( $\mathrm{SiO}_{2}$ content up to $\left.92 \%\right)$ is used as a component of moulding or core sand mixtures for iron or non-ferrous casting, as well as the production of construction materials and bottle glass.

10. Soda-alkaline technology uses easily accessible and inexpensive sodium carbonate (soda) and potassium chloride instead of a rare and expensive potassium carbonate (potash).

Comparative technical and economic estimates for soda-alkaline and potash-alkaline technologies, under an expected productivity of 150.000 tonnes of $\mathrm{AL}_{2} \mathrm{O}_{3}$ per annum, demonstrated:

A. Annual financial efficiency of soda-alkaline technology: USD 200.902 million per annum.

B. Annual financial efficiency of potash-alkaline technology: USD 159.571 million per annum.

Note: the USA is the second largest producer of soda ash $\left(\mathrm{Na}_{2} \mathrm{CO}_{3}\right)$ in the world, and Canada is the world's largest producer of potassium chloride $(\mathrm{KCl})$.

\section{References}

Agranovsky, A. A. USSR Author certificate No 106048, Discoveries and Inventions 26.

Labutin, G. V. (1948). Technology of Alunite Recovery. USSR author certificates 9911 and 108947

Labutin, G. V. (1965). Alunites Metallurgy. Moscow, 34-90.

Lainer, A. I., Zakharova, V. I., Popelukhina, M. I., Lainer, Y. A., Taghiyev, E. I., \& Pevzner, I. Z. (1974). USSR Author certificate, 460709, October 21, 1974

Lainer, Y. A. (1982). Integrated Processing of Aluminium-containing Raw Materials by Acidic Matters. 18-23, Moscow: Nauka

Nasyrov, G. Z., \& Nemets, N. V. (1995). Conversion of Mixture of Potassium and Sodium Sulphates with Potassium Chloride. USSR Author certificate 784156 of June 14, 1979, VAMI

Nasyrov, G. Z., \& Nemets, N. V. (2005). Method of Processing of Alunite Ore to Potassium Alums and Aluminium Sulphate.

Piga, L. et al. (1999). Beneficiation of Alunite by Piro-and hydrometallurgical Treatment of Alunite $-\mathrm{K}_{2} \mathrm{CO}_{3}$ mixtures. Miner Metall Process, 16(2), 20-24. https://doi.org/10.1007/BF03402803

Potash Ridge Corp, Technical Report, dated April 24, 2017. Project Number 17M16 (source: Internet)

Shahab, A. (2016). Alunite Processing Method Selection using the AHP and TOPSIS Approaches under Fuzzy Environment. International Journal of Mining Science and Technology, 26, 1017-1023. https://doi.org/10.1016/j.jimst.2016.09.009

Sizyakov, M. V., \& Nasyrov, G. Z. (2001). Effective Methods for the Integrated Processing of Non-bauxite Aluminosilicate Raw Material on Alumina and Side-line Products. Tsvetniye Metally, 12, 63-69.

Smirnov-Verin, S. (1938). Alunites and their Use. 114, ONTI

Taghiyev, E. I. (2001). Patent of the Azerbaijan Republic I 20010142 of 2 October 2001

Taghiyev, E. I. (2003). Patent of the Azerbaijan Republic I 20030210 of 30 October 2003

Taghiyev, E. I. (2006). Technology of an Integrated Waste-free Processing of Alunite Ore. 504. Baku, Elm.

Taghiyev, E. I., \& Agajeva, L. (2019). Cost Effective Technology of Alunite Ore Processing. International Journal of Chemistry, 11(1), 36-44. The Canadian Center of Science and Education (CCSE). 
https://doi.org/10.5539/ijc.v11n1p36

Taghiyev, E. I., Agajeva L., \& Tagijev, E. (2018). Patent of Czech Republic 307974 of January 30, 2018.

Taghiyev, E. I., Babayev, I. S., Radjabli, S. B., Khoudiyev, A. T., \& Aliyev, T. B. (1981). USSR Author certificate 872456, 15 June 1981.

\section{Copyrights}

Copyright for this article is retained by the author(s), with first publication rights granted to the journal.

This is an open-access article distributed under the terms and conditions of the Creative Commons Attribution license (http://creativecommons.org/licenses/by/4.0/). 